\title{
Evaluation of Poisoning and Drug Overdose among Cases Presented to Poison Control Centre, Ain Shams University Hospital during the Year 2015
}

\author{
Hany M. Tawfik ${ }^{1}$ and Eman A. Khalifa ${ }^{2}$ \\ ${ }^{1}$ Assistant consultant of clinical toxicology, Poison Control Center \\ ${ }^{2}$ Department of Forensic medicine and Clinical Toxicology, Faculty of Medicine \\ Ain Shams University, Cairo, Egypt
}

\begin{abstract}
Background: Poisoning and drug overdose are important health problems in developing countries. The Poison Control Center of Ain Shams University Hospitals (PCCA) was established in 1981 as first one of its kind in the Middle East. Since then it has provided adequate services in diagnosis and treating cases of intoxication. The information released by the PCC has always been a trigger for an increasing hazard challenging the community.

The aim of the study: To assess the prevalence of poisoning and to review the determinants, circumstances and outcome of patients with intoxication in PCCA, Egypt during the year 2015 to recognize changes in trends of poisoning to highlight threats to which the Egyptian community is exposed. Methods: This is a retrospective observational hospital record-based study conducted in PCCA, Egypt. In the present study, 21898 cases of poisoning including all admissions during one year (2015) were investigated.Data on demography, hospitalization, type of poison/drug, clinical and management data and outcome of patients with poisoning were collected. Data were analyzed using descriptive analysis and statistics.,

Results: This study included 21898 cases.Most cases of acute poisoning presented among 15-40 years age group (59.2\%), 25.4\% under 7 years old. Incidence was more common among females (54.8\%) compared to males (45.2\%). More than $94 \%$ of cases were toxic exposure through oral route.Most poison exposures were unintentional (49.5\%).Drug poisoning constituted the majority of cases (55.1\%), while non-drug poisoning was the second in incidence (44.9\%), CNS drugs (9.95\%) were the most common drugs involved, chemicals (24.1\%), were the commonly used poisons. Clinical severity was mild in $81.3 \%$ of cases, $13.2 \%$ was moderate and $5.5 \%$ was severe. Mortality was found to be $0.56 \%$. Management of these cases was described.

Conclusions: Poisoning is more common in15-40 age group followed by children younger than 7 years. CNS drugs were the most common consumed drugs over-dosage, while chemicals were the most common among poisons. There is a change in pattern of poisoning as regard decline in number of poisoning cases from kerosene and petroleum distillates, drug of abuse overdose and animal envenomation. In addition poisoning by drugs outnumbered non- drug poisoning.
\end{abstract}

\section{Introduction}

$\mathrm{D}$ eliberate self-harm is a major public health problem in many developing countries (Chowdary et al.,2007). Each year, 500,000 deaths occur in rural Asia due to suicide. Poisoning is the leading cause of injury-related death in the U.S.Acute poisoning is an important medical emergency. The nature of poison used varies in different parts of the world and may vary even in different parts of the same country .Management of these critically ill patients will greatly improve if the common causes of poisoning are properly identified(Ramesha et al, 2009).

It is important to know the nature and severity of poisoning in order to take appropriate preventive measures. Studies of this nature will be a useful tool in planning and management of critically ill acute poisoning cases (Ramesha et al, 2009).

Poison Control Centre (PCC) is witnessing a continuously changing poisoning pattern (El 
Masry and Tawfik , 2013).The pattern and characteristics of acute poisoning differ from country to country. Thus, special epidemiological surveillance from each country is necessary to determine the problem according to which preventive measures can be taken (Gamalludin et al., 2006).

The pattern of poisoning within a country depends on several factors such as the accessibility of various poisons, socio-economic status of the population, religious and cultural influences and drug prescription manners (Zhao et al., 2009).

\section{Aim of the Work}

The aim of this study is assessment of the pattern and circumstances of poisoning in PCCA during year 2015, and to highlight different changes in trends of this problem. Interpretation of the poisoning data through an annual report would be essential to face continuously emerging challenging hazards and will enable us to issue warning reports in order to provide some preventative regulations for the community concerning with poisoning burden.

\section{Patients and methods}

This is retrospective hospital record-based study was carried out on the basis of data collected from the Poison Control Centre in Ain Shams University Hospitals, during the year 2015. A total of 21898 poisoning cases were overviewed. Data were collected from medical records of all patients admitted to the Emergency Department after approval from director of PCCA and confidentiality issues were considered. The variables in the present study were age, gender, type, route, mode of the poison taken, residence, severity, outcome and management. Data collected throughout the study period were tabulated and statistically analyzed using SPSS statistical program.

\section{Results}

The majority of poisoning were remarkably found in the age group of $15-40$ years (59.2\%) followed by children younger than 7 years accounted for approximately quarter of all exposures(25.4\%), and $8.6 \%$ of the patients were above 40 years of age (Table 1). Incidence of toxic exposure was more common among females (54.8\%) compared to males (45.2\%) (Table 2 ).

Most of cases originated from greater Cairo (69.2\%) followed by the nearby Kalioubeya (16.2\%), Giza (8.9\%), and all other governorates represented 5.7\% of the cases (Table 3)

The common route of consumption of poison was oral (94.4\%), followed by accidental inhalation (2.8\%).The reason category for most exposures was unintentional (49.5\%), suicidal intention was reported among $43.9 \%$, followed by drug abuse overdose in $6.5 \%$, therapeutic error (0.07\%) and criminal poisoning represented the least number of cases (6 cases - 0.03\%) (Table 4, 5).

In the present study, the most frequent causes of intoxication were due to pharmaceuticals (55.1\%), and non-drugs were responsible for 44.9\% (Table 6).The drug poisoning was remarkably due to centrally acting drugs (9.95\%), where antidepressants was the most frequent one(3.5\%),followed by analgesics (7.7\%).Drugs of abuse were responsible for $6.8 \%$ of drug poisoning where tramadol represented the majority of cases (3.8 ) (Table 7, Figure1).

Amongst the non-drug poison, the highest percentage was related to chemicals, chemical poisoning comprised $24.1 \%$ of recorded cases while organophosphorous poisoning alone accounted for $10 \%$ of cases. Cases presented with food poisoning were $14.23 \%$, animal poisoning was seen in $2.3 \%$ of which $1.5 \%$ were due to scorpion stings, $0.8 \%$ were due to snakebites. However toxic gases poisoned cases were $2.22 \%$ which involved mainly carbon monoxide poisoning. The least number of cases of non-drug poisoning was due to plants where only 4 cases $(0.02 \%)$ were received (Table 8, Figure 2).

According to Persson et al., (1998), poisoning severity was mild in the majority $(81.3 \%)$ of cases, moderate in $13.2 \%$ and severe in 5.5\% (Table 10).Table (11) shows duration of hospital stay, majority of patients in the study were observed for 6 hours, while $13.2 \%$ had a stay for less than one day and $4.7 \%$ of cases were admitted for $1-4$ days. Only $0.5 \%$ stayed in the hospital for more than 7 days. There was significant relation between hospitalization days and mortality (Table 12, Figure 5). .

Among all patients, the mortality rate was $0.56 \%$.The leading cause of death was organophosphate (24 cases), followed by tramadol (18 cases), methanol (13 cases), opiate (9 cases) and corrosive (8 cases). The other causes of death from different poisons are shown in (Table 13).There were more mortalities among patients with poisoning compared to patients with drug over dosage.

Tables (14) outline the use of emergency measures, decontamination procedures, measures to enhance elimination, specific antidotes, and supportive measures in the treatment of patients.

Ipecac-induced emesis for poisoning no longer be used, enhanced elimination in the form of activated charcoal was administered for $5.1 \%$, while hemodialysis was the mainstay treatment of 21cases $(0.1 \%)$. Atropine and obidoxime were the most common antidotes used followed by snake and scorpion anti venom followed by naloxone administration. In $93 \%$ of patients, no specific antidote was used. Mechanical ventilation was needed in 197cases $(0.9 \%)$. 
Table (1): The age distribution of poisoned cases received in PCCA through the year 2015

\begin{tabular}{|l|l|l|}
\hline Age (yrs) & No & $\mathbf{\%}$ \\
\hline$<7$ & 5562 & 25.4 \\
\hline $7-<15$ & 1402 & 6.4 \\
\hline $15-<25$ & 7533 & 34.4 \\
\hline $25-40$ & 5431 & 24.8 \\
\hline$>40$ & 1883 & 8.6 \\
\hline unknown & 87 & 0.4 \\
\hline Total & 21898 & 100 \\
\hline
\end{tabular}

Table (2): The sex distribution of poisoned cases received in PCCA through the year 2015

\begin{tabular}{|l|l|l|}
\hline Sex & No & \% \\
\hline Female & 12000 & 54.8 \\
\hline Male & 9898 & 45.2 \\
\hline Total & 21898 & 100 \\
\hline
\end{tabular}

Table (3): The Residence of poisoned cases received in PCCA through the year 2015

\begin{tabular}{|l|l|l|}
\hline Region & No & $\mathbf{\%}$ \\
\hline Cairo & 15153 & 69.2 \\
\hline Kalioubeya & 3548 & 16.2 \\
\hline Giza & 1949 & 8.9 \\
\hline Other Governorates & 1248 & 5.7 \\
\hline Total & 21898 & 100 \\
\hline
\end{tabular}

Table (4): The routes of poisoning of poisoned cases received in PCCA through the year 2015

\begin{tabular}{|l|c|c|}
\hline \multicolumn{1}{|c|}{ Route } & No & $\mathbf{\%}$ \\
\hline Ingestion / Oral & 20670 & 94.4 \\
\hline Inhalation / nasal & 611 & 2.8 \\
\hline Bite / sting & 504 & 2.3 \\
\hline Dermal / skin & 49 & 0.2 \\
\hline Injection & 64 & 0.3 \\
\hline Total & 21898 & 100 \\
\hline
\end{tabular}

Table (5): Mode of poisoning of poisoned cases received in PCCA through the year 2015

\begin{tabular}{|c|c|c|}
\hline Mode & No & $\%$ \\
\hline Accidental & 10844 & 49.5 \\
\hline Suicidal & 9612 & 43.9 \\
\hline Overdose drug of abuse & 1422 & 6.5 \\
\hline Therapeutic error & 14 & 0.07 \\
\hline Criminal & 6 & 0.03 \\
\hline Total & 21898 & 100 \\
\hline
\end{tabular}

Table (6): Type of causative agents of poisoned cases received in PCCA through the year 2015

\begin{tabular}{|l|c|c|}
\hline Type & No & \% \\
\hline Drug poisoning & 12066 & 55.1 \\
\hline Non- drug poisoning & 9832 & 44.9 \\
\hline Total & 21898 & 100 \\
\hline
\end{tabular}


Table (7): Drugs involved in poisoned cases received in PCCA through the year 2015

\begin{tabular}{|c|c|c|}
\hline Drug & No & $\%$ \\
\hline \multicolumn{3}{|c|}{ Addiction drug $6.8 \%$} \\
\hline Tramadol & 832 & 3.8 \\
\hline Cannabis & 482 & 2.2 \\
\hline Opiate & 175 & 0.8 \\
\hline \multicolumn{3}{|c|}{ Centrally acting drugs $9.95 \%$} \\
\hline Benzodiazepine & 482 & 2.2 \\
\hline TCA & 759 & 3.5 \\
\hline SSRI & 22 & 0.1 \\
\hline Lithium & 7 & 0.03 \\
\hline Psychotropic & 504 & 2.3 \\
\hline Carbamazepine & 285 & 1.3 \\
\hline Other antiepileptic & 66 & 0.3 \\
\hline Anticholinergic & 22 & 0.1 \\
\hline Cogentin & 5 & 0.02 \\
\hline Baclofen & 22 & 0.1 \\
\hline \multicolumn{3}{|l|}{ Analgesics $7.7 \%$} \\
\hline NSAIDs & 920 & 4.2 \\
\hline Paracetamol & 613 & 2.8 \\
\hline Salicylate & 153 & 0.7 \\
\hline \multicolumn{3}{|c|}{ Cardiovascular drugs $5.72 \%$} \\
\hline Theophylline & 723 & 3.3 \\
\hline Beta Blockers & 329 & 1.5 \\
\hline Antihypertensive & 175 & 0.8 \\
\hline Digoxin & 22 & 0.1 \\
\hline Calcium Channel Blocker(CCB) & 5 & 0.02 \\
\hline \multicolumn{3}{|c|}{ Antidiabetic medication $2.1 \%$} \\
\hline Insulin + Oral hypoglycaemic & 464 & 2.11 \\
\hline \multicolumn{3}{|l|}{ Others $22.8 \%$} \\
\hline Antibiotics & 985 & 4.5 \\
\hline Oral Contraceptive Pills (OCP) & 311 & 1.42 \\
\hline Antihistaminic & 372 & 1.7 \\
\hline Vitamins & 241 & 1.1 \\
\hline Flagyl & 176 & 0.8 \\
\hline Unknown drug & 2738 & 12.5 \\
\hline Miscellaneous & 176 & 0.8 \\
\hline Total & 12066 & 55.1 \\
\hline
\end{tabular}


Table (8):Non-drug most frequently involved in poisoned cases received in PCCA through the year 2015

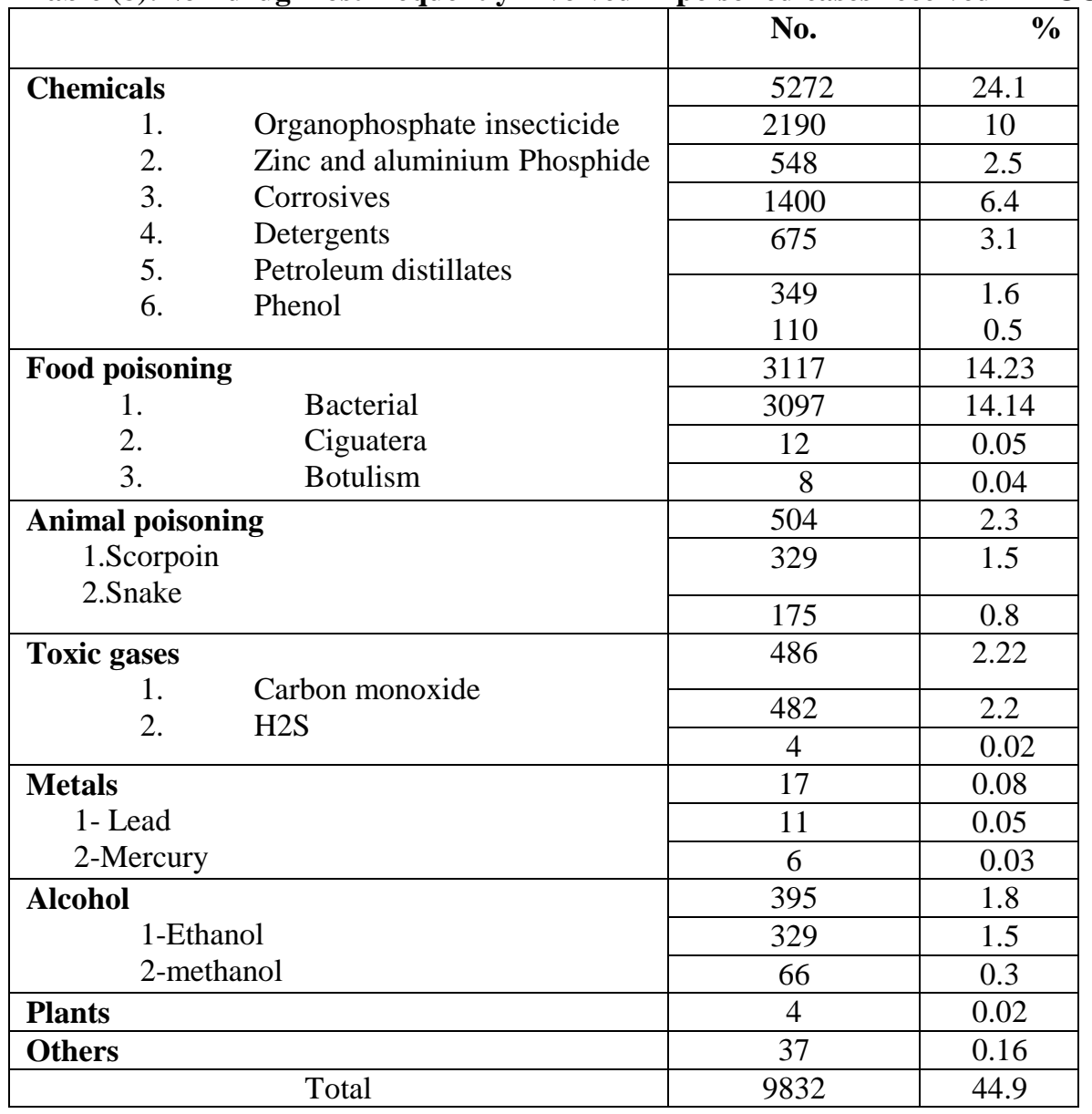

Table (9): Top 10 most frequently involved exposure substance

\begin{tabular}{|l|l|}
\hline All exposures & Percent \\
\hline Bacterial food poisoning & 14.14 \\
\hline Organophosphate & 10 \\
\hline Corrosives \& detergents & 9.5 \\
\hline Antibiotics & 4.5 \\
\hline NSAIDs & 4.2 \\
\hline Tramadol & 3.8 \\
\hline TCA & 3.5 \\
\hline Theophylline & 3.3 \\
\hline Paracetamol & 2.8 \\
\hline Phosphide poisoning & 2.5 \\
\hline
\end{tabular}

Table (10): Grading of poisoning severity of cases received in PCCA through the year 2015(Persson et al., 1998).

\begin{tabular}{|l|c|c|}
\hline Degree of severity & No & $\mathbf{( \% )}$ \\
\hline Mild & 17813 & 81.3 \\
\hline Moderate & 2889 & 13.2 \\
\hline Severe & 1196 & 5.5 \\
\hline Total & 21898 & 100 \\
\hline
\end{tabular}


Table (11): The period of hospitalization of poisoned cases received in PCCA through the year 2015

\begin{tabular}{|c|c|c|}
\hline Period of hospitalization & No & $\mathbf{( \% )}$ \\
\hline$<$ 6hours & 17813 & 81.3 \\
\hline 6 hours $-<1$ day & 2910 & 13.2 \\
\hline$>1$ day -4 days & 1021 & 4.7 \\
\hline$>4$ days $-<7$ days & 56 & 0.3 \\
\hline$>7$ days & 98 & 0.5 \\
\hline Total & 21898 & 100 \\
\hline
\end{tabular}

Table (12): Relation between the outcome and the period of hospitalization of poisoned cases received in PCCA through the year 2015.

\begin{tabular}{|c|c|c|c|c|}
\hline Period of hospitalization & $\begin{array}{c}\text { Survivors } \\
\text { No (\%) }\end{array}$ & Non-survivors No (\%) & $\mathbf{X}^{2}$ & P-value \\
\hline$<$ 6hours & $17809(81.78)$ & $4(3.3)$ & \multirow[t]{5}{*}{2823.581} & \multirow[t]{5}{*}{$<0.001$} \\
\hline 6 hours $-<1$ day & $2870(13.2)$ & $40(32.5)$ & & \\
\hline$>1$ day -4 days & $988(4.54)$ & $33(26.8)$ & & \\
\hline$>4$ days $-<7$ days & $33(0.15)$ & $23(18.7)$ & & \\
\hline$>7$ days & $75(0.34)$ & 23(18.7) & & \\
\hline
\end{tabular}

$P<0.05 *$ : Significant. $X 2$ Relation between the outcome and hospital stay in the studied cases.

Table (13): Types of poisoning and mortality

\begin{tabular}{|l|c|}
\hline Type of poisoning & Mortality(\%) \\
\hline OP & $24(19.51)$ \\
\hline Tramadol & $18(14.63)$ \\
\hline Methanol & $13(10.57)$ \\
\hline Opiate & $9(7.32)$ \\
\hline Corrosive & $8(6.5)$ \\
\hline CO & $6(4.88)$ \\
\hline Phosphide & $4(3.25)$ \\
\hline Carbamazepine & $4(3.25)$ \\
\hline Benzodiazepines & $3(2.44)$ \\
\hline Kerosene & $3(2.44)$ \\
\hline Digoxin & $2(1.63)$ \\
\hline Oral hypoglycaemic & $2(1.63)$ \\
\hline TCA & $2(1.63)$ \\
\hline Snake & $2(1.63)$ \\
\hline Scorpion & $1(0.81)$ \\
\hline Neuroleptic & $1(0.81)$ \\
\hline Antihistaminic & $1(0.81)$ \\
\hline B-blocker & $1(0.81)$ \\
\hline unknown & $19(15.45)$ \\
\hline Total & $123(100)$ \\
\hline
\end{tabular}


Table (14): Interventions offered to acutely poisoned cases received in PCC through the year 2015.

\begin{tabular}{|l|c|}
\hline Type of intervention & No (\%) \\
\hline \multicolumn{2}{|c|}{ Emergency treatment } \\
\hline Endotracheal intubation & $\left.237(1 .)^{\prime}\right)$ \\
\hline $\begin{array}{l}\text { Decontamination } \\
\text { Gastric lavage }\end{array}$ & $\left.-242(1 .)^{\prime}\right)$ \\
Skin wash & $15\left(0.0^{\vee}\right)$ \\
\hline \multicolumn{2}{|c|}{ Enhanced elimination } \\
\hline Activated charcoal & $\left.1116(5 .)^{\prime}\right)$ \\
Dialysis & $21(0.1)$ \\
Bicarbonate & $41(0.2)$ \\
\hline \multicolumn{2}{|c|}{ Antidote } \\
\hline Atropine & 619 \\
\hline Obidoxime & 183 \\
\hline Snake anti-venom & 325 \\
\hline Scorpion anti-venom & 138 \\
\hline Naloxone & 121 \\
\hline Hyperbaric O2 therapy & 29 \\
\hline Ethanol & 24 \\
\hline N-acetylcysteine & 23 \\
\hline Glucagon & 13 \\
\hline Flumazenil & 9 \\
\hline Methylene blue & 9 \\
\hline Antibotulinum & 8 \\
\hline Calcium gluconate & 5 \\
\hline & \\
\hline Mechanical Ventilation & $197(0.9)$ \\
Manitol & 34 \\
\hline
\end{tabular}

Table (15): Characteristics of available literatures including poisoning agents worldwide on comparison with the present study.

\begin{tabular}{|l|l|l|l|l|l|l|l|l|l|} 
& $\begin{array}{l}\text { No. of } \\
\text { cases }\end{array}$ & Country & $\begin{array}{l}\text { Age } \\
\text { group }\end{array}$ & Sex & Route & Mode & $\begin{array}{l}\text { Duration of } \\
\text { the study }\end{array}$ & $\begin{array}{l}\text { Leading } \\
\text { agent }\end{array}$ & $\begin{array}{l}\text { death } \\
\text { rate }\end{array}$ \\
\hline $\begin{array}{l}\text { Hegazy et al } \\
2012\end{array}$ & 330 & $\begin{array}{l}\text { Saudi } \\
\text { Arabia }\end{array}$ & $<4 y$ & $\begin{array}{l}\mathrm{F} \\
>\mathrm{M}\end{array}$ & oral & accidental & 2 ys & Drugs & $0.6 \%$ \\
\hline $\begin{array}{l}\text { Anthony and } \\
\text { kulkarni,2012 }\end{array}$ & 296 & India & $21-30 y$ & $\begin{array}{l}\mathrm{M}> \\
\mathrm{F}\end{array}$ & oral & suicidal & $15 \mathrm{Ms}$ & Non-drug & $2.4 \%$ \\
\hline $\begin{array}{l}\text { Annual report } \\
\text { PCCA,2015 }\end{array}$ & 21898 & $\begin{array}{l}\text { Egypt } \\
\text { (PCCA) }\end{array}$ & $\begin{array}{l}15-40 \\
\mathrm{y}\end{array}$ & $\begin{array}{l}\mathrm{F} \\
>\mathrm{M}\end{array}$ & oral & accidental & $12 \mathrm{Ms}$ & Drugs & $0.56 \%$ \\
\hline $\begin{array}{l}\text { Mowry et al., } \\
\text { 2015 }\end{array}$ & $\begin{array}{l}2.2 \\
\text { million }\end{array}$ & US & $\begin{array}{l}\text { Below } \\
6 y\end{array}$ & $\begin{array}{l}\mathrm{F} \\
>\mathrm{M}\end{array}$ & oral & accidental & $12 \mathrm{Ms}$ & Drugs & $0.05 \%$ \\
\hline Jalali et al,2012 & 3258 & Iran & $\begin{array}{l}18-30 \\
\mathrm{y}\end{array}$ & $\mathrm{M}=\mathrm{F}$ & stings & suicidal & $12 M s$ & envenomation & $0.3 \%$ \\
\hline
\end{tabular}




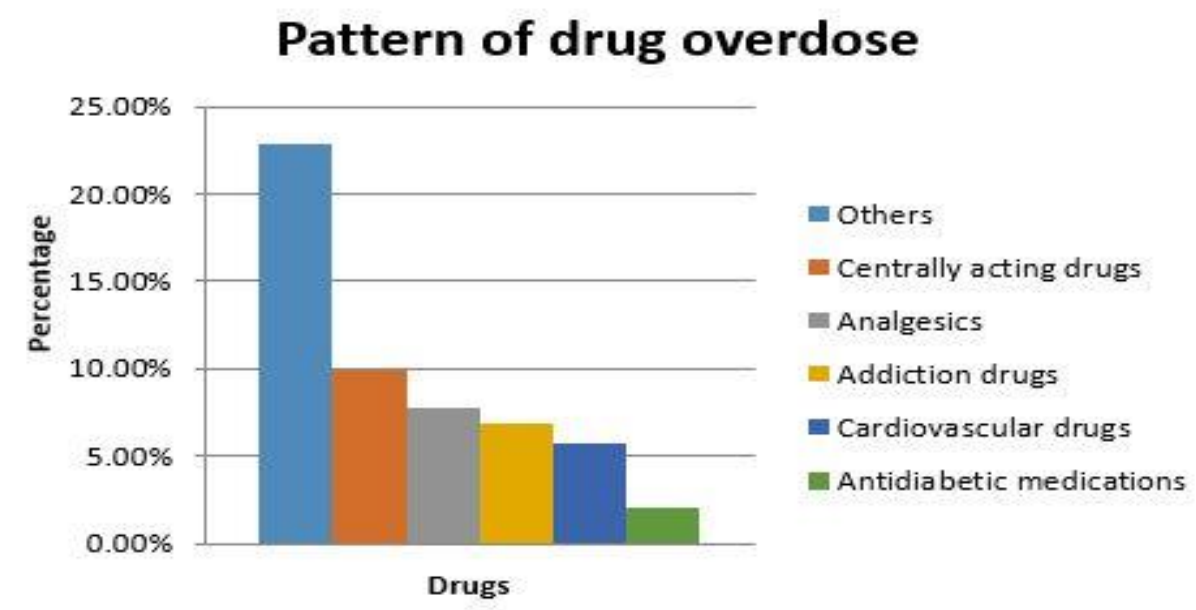

Figure (1): Pattern of drug overdose in poisoned cases received in PCCA through the year 2015

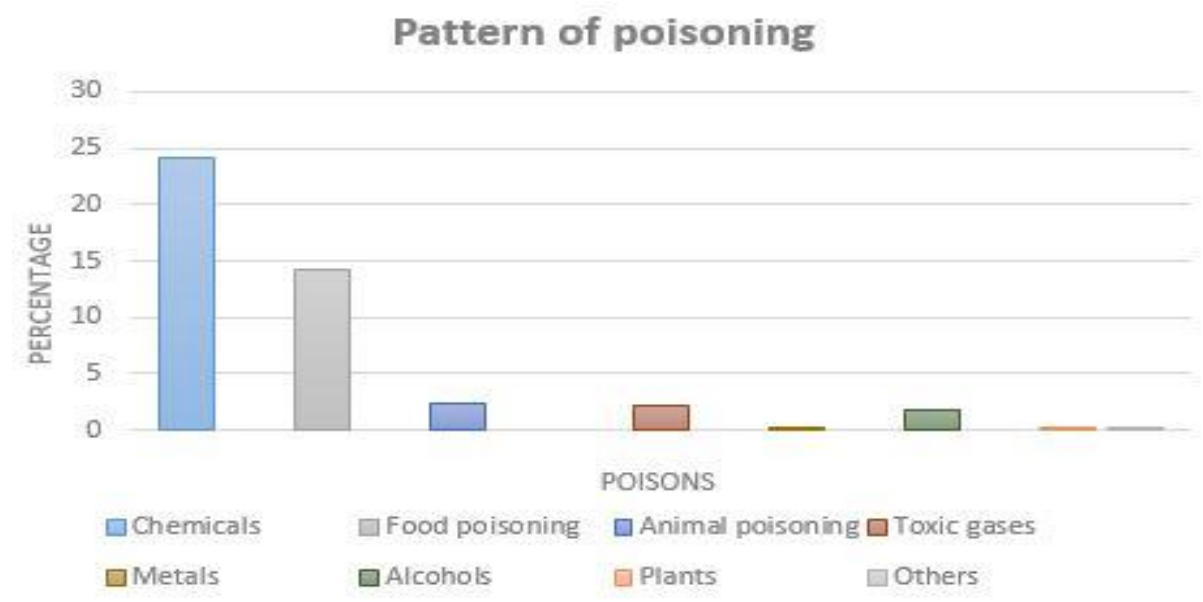

Figure (2): Pattern of poisoning in poisoned cases received in PCCA through the year 2015.
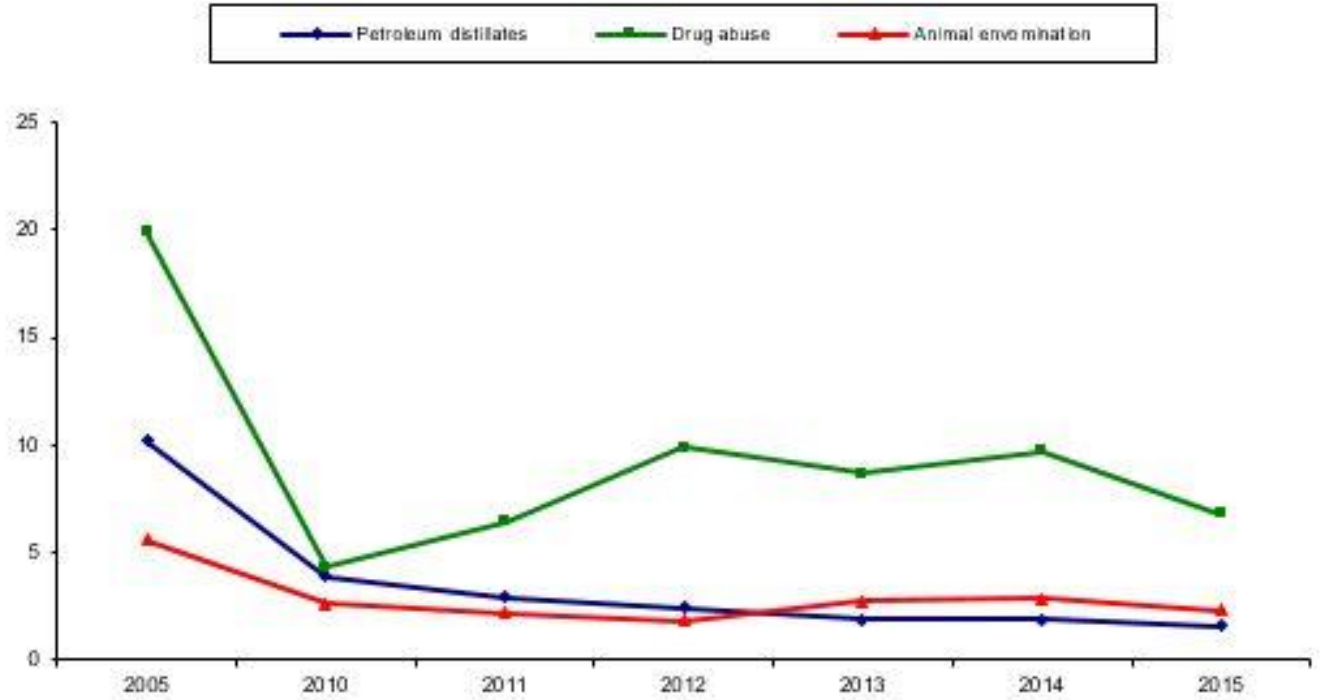

Figure (3): Yearly variation of some intoxications presented to PCCA. 


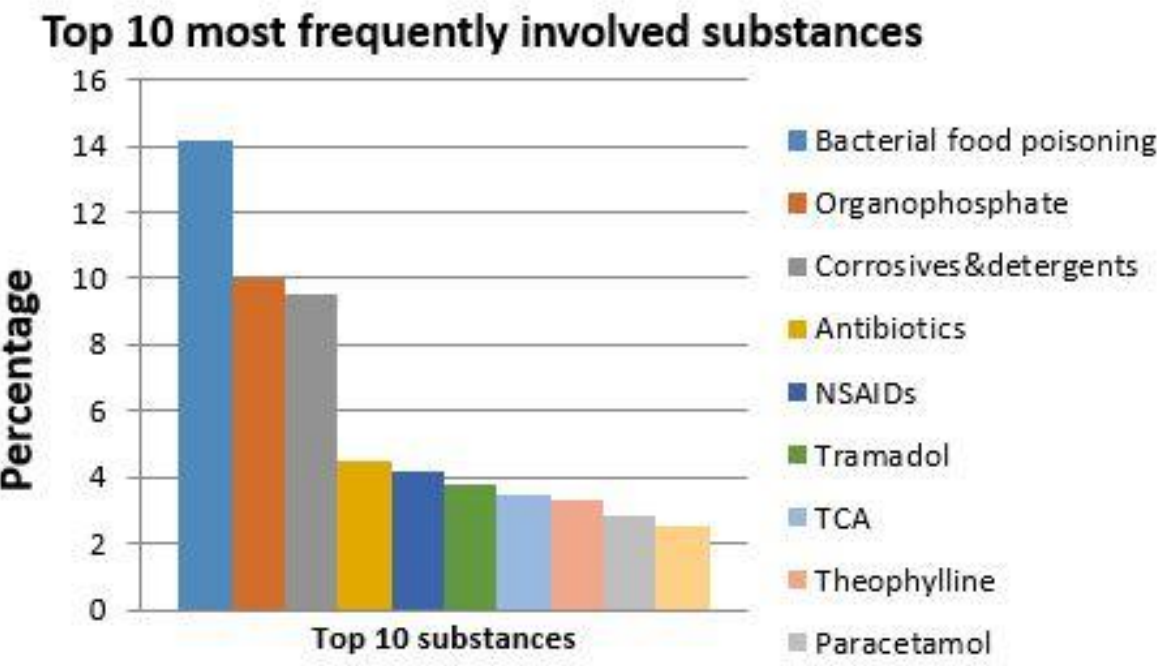

Figure (4): Top 10 most frequently involved substances in PCCA through the year 2015.

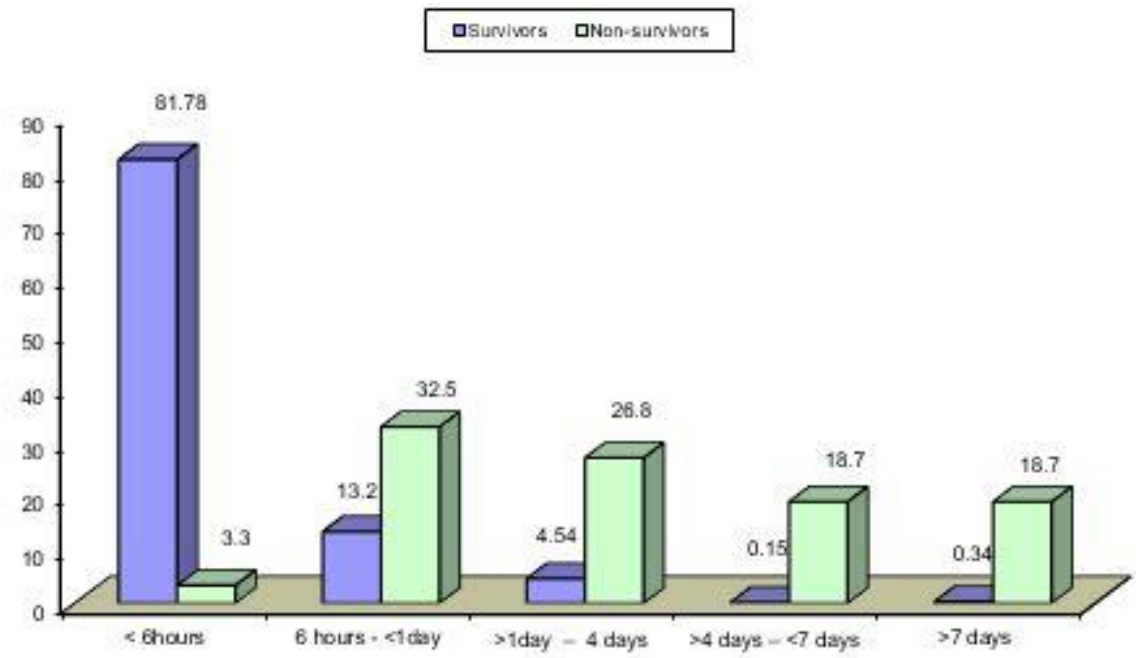

Figure (5): Relation between the outcome and hospital stay in the studied cases.

\section{Discussion}

The PCCA is the first established national poison treatment center of Egypt received large number of poisoned patients yearly. The current study involved investigation of more than twenty thousand medical records of poisoning from different age groups.Total encounters increased from 21650 in 2014 to 21898 in 2015.

In this study, majority of the poisoning cases presented between 15 and 40 year age group (59.2\%).This is similar to a study conducted in Iran which reported that the 18-30 age group is more liable to poisoning(Jalali A et al.,2012).This was in accordance with Zhou et al., 2005 who reported that at China emergency hospitals the age group between 15-34 years was the highest presentable age group and in an Indian study by Anthony and Kulkarni,2012 ,54.9\% of cases were in the age group of 21-30 years. A possible explanation could be factors like financial, emotional, and social stresses.

In contrast to other countries whether of arab ic or western culture revealed that children below 5 years represented the majority of cases of poisoning (Sibert and Davies,1992,Saddique, 2001; Izuora and Adeoye, 2001) The 2014 annual report of the American Association of Poison Control Centres revealed that children younger than 6 years accounted for approximately half of all human exposures (47.7\%)(Mowry et al., 2015).

The gender distribution in this study showed that female presentation (54.8\%) was more than that of male presentation (45.2\%).Similar findings were observed in other studies (Satar and Seydaoglu 2005 ,Rhodes et al.,2008 and Ram et al.,2014).This could be 
explained as females are more vulnerable to psychological and emotional stresses.

However, males outnumbered females, as found in the literature (Ramesha et al,2009 and Anthony and Kulkarni,2012).While according to studies in Saudi Arabia and Iran, males and females were both affected similarly(Barrag and Farahat 2011 and Jalali A et al.,2012).

The residence distribution of patients in this study showed $69.2 \%$ from Cairo followed by Kalioubeya and Giza where they represented $16.2 \%$ and $8.9 \%$ respectively and all other governorates constituted 5.7\% of cases. This distribution was similar to study in India, which revealed predominance of poisoning in urban areas (92\%)(Anthony and Kulkarni, 2012).This is attributed to the proximity of these governorates to the PCCA and not reflect the higher magnitude of the poisoning health problem.

More than $94 \%$ of the cases under the current study were exposed through oral route compared to (2.8\%), (2.3\%), $(0.3 \%)$ and $(0.2 \%)$ cases through inhalation envenomation, injection, and dermal, respectively. This agreed with results of other studies where ingestion was the main route of exposure(Barrag and Farahat 2011,El Masry and Tawfik , 2013, Mowry et al., 2015 ).Oral route was the most common route of poisoning decreasing the possibility of occupational and environmental toxicity and increasing the potential for suicidal attempts or household exposure.

Cases with accidental exposure (49.5\%) exceeded that of attempted suicide (43.9\%).this was similar to Barrag and Farahat 2011 Mowry et al., 2015 who reported that most poison exposures were unintentional. This data was against other reported studies where it was found that majority of the patients had intentionally used the poisons to induce self-harm (Ramesha al, 2009,Anthony and Kulkarni, et 2012).

In 2015 in the current study, 55.1\% of exposures involved medications, or pharmaceuticals and $44.9 \%$ was non-drug poisoning. This was in agreement with poisoning pattern of other studies where drugs were the most common causes of poisoning (AlArifi et al., 2003, Rajasuriya et al 2007 ,Halwa et al, 2013 Mowry et al., 2015).

Some other studies showed that majority of poisoning admissions were due to non-drug toxicity (Gamalludin et al, 2006, Ramesha et al, 2009,Anth,ony and Kulkarni, 2012).

Some of the reasons that drugs were a major problem in several reports include free medical treatment, an easy access to medications without even prescriptions in addition to the careless storage of drugs inside homes (Barrag and Farahat 2011).

The top 10 substance classes most frequently involved in all poison exposures in this study were bacterial food poisoning (14.14\%), organophosphate (10\%), corrosives \& detergents (9.5\%), , antibiotics (4.5\%), NSAIDs (4.2\%), tramadol (3.8\%), TCA (3.5\%),theophylline $\quad(3.3 \%)$ paracetamol(2.8\%) and phosphide poisoning (2.5\%).

CNS depressants reported as the highest in the current study followed by analgesics. The same was found in a study in Iran which reported that CNS acting drugs were the commonest (Jalali A et al.,2012 ), while Barrag and Farahat 2011 study reported paracetamol being the highest in Saudi Arabia. Also in the US the most frequent types of drug ingestion reported by poison centers during 2014 were analgesics (Mowry et al., 2015).

Regarding non-drug toxicity, $24.1 \%$ of cases of poisoning were due to chemicals, of these cases, $12.5 \%$ were due to insecticides. This high percentage may be due to easy availability of insecticides and large scale of its use. This was similar to India where pesticides was the most common type of poisoning (Ramesha et al, 2009, Anthony and Kulkarni, 2012).

This variation in the type of poisoning seen within each country may be due to cultural differences between countries together with differences in the availability of poisonous agents.

AAnimal bites and sting decreased from 5.59\% in 2005 to $2.3 \%$ in 2015. There was decrease in the number of cases with intentional abuse (6.5\%) compared to a similar study at PCCA in 2005, in which it was (12.7\%) (Gamalludin et al, 2006).A decline was also observed in tramadol overdose as year-to-year change showed $7.4 \%$ in $2011,8 \%$ in $2012,6.9 \%$ in $2013,7.3 \%$ in 2014 and 3.8\% in 2015. Another impressing finding is the significant decrease of kerosene and petroleum distillates intoxications from $10.21 \%$ on 2005 to $1.6 \%$ on 2015 reflects the decline in use of these chemicals.

This study showed that, most of poisoned cases (81.3\%) were mild, while moderate cases were $13.2 \%$ and severe cases were 5.5\%.Similar results were found by Gamalludin et al, 2006 and El Masry and Tawfik , 2013 where poisoning severity was mild in the majority of cases.

Majority of patients (81.3\%) in the present study had a short hospital stay of less than 6 hours, this could be attributed as most of cases were mild and was discharged or managed by observation at ER.

Moreover, the duration of stay in hospital correlated significantly with the mortality in this study where the longer the duration of hospitalization the more incidence of death. In contrast to the current study, a study done in India 2010 reported that the duration of hospital stay not correlate with the mortality (Anthony and Kulkarni, 2012).

The overall mortality in this study was $0.56 \%$ .Shadnia, 2007 found that mortality rate in Tehran 2003 was $1.3 \%$. Another report from Saudi Arabia, 1999-2003 revealed a mortality rate of $2.2 \%$ (Moazzam et al., 2004) .The literature shows fatality rate in UK, is less than $0.5 \%$, in Sri Lanka it is $7 \%$ and in India it is $30 \%($ Anthony and Kulkarni, 2012). When interpreting the low mortality rate in this study, it is important to consider that 
many cases were mild or moderate poisoning presentations.

Furthermore, the presented data (Table 13) indicates that organphosphorous pesticides are the main cause of death, this could be explained by the fact that most of cases presented were due to organophosphate make the organophosphate problem of particular concern, and invite for more rigid regulations concerning its misuse.

In the current study, activated charcoal was the most frequent decontamination procedure undertaken for poisoned cases. Ipecac-induced emesis for poisoning continues to decline as observed in this study where Ipecac no longer be used compared to study by El Masry and Tawfik , 2013, where $24 \%$ of cases consumed ipecac as an emetic. The American Academy of Pediatrics concluded not only that ipecac should no longer be used routinely as a home treatment strategy, but also recommended disposal of home ipecac stocks (American Academy of Pediatrics, 2003).

The most frequently used antidotes were atropine and obidoxime reflecting the large number of received organophosphate poisoning cases.Ramesha et al, 2009 stated that the first aid given with considerable value among poisoned cases admitted to medical institution in India was gastric lavage and dosage schedule of various antidotes such as atropine and antisnake venom.

\section{Conclusions}

15-40 age group was more liable to poisoning and children younger than 7 years accounted for more than $25 \%$ of all exposures.

CNS depressants followed by analgesics were the most common drugs encountered poisons, while bacterial food poisoning and chemicals especially insecticides were the most common non- drug toxicity.

There is a change in the pattern of poisoning as regard marked decrease in the total number of poisoning cases from kerosene and petroleum distillates and also decline in drug of abuse overdose and in animal envenomation cases. In addition poisoning by pharmaceuticals outnumbered non- drug poisoning.

\section{Recommendations}

It is recommended to provide training programs to physicians and raising awareness of the public to decrease the possibility of exposure, as well as enhance the proper action in case of poisoning.

Legislations should be implemented to ban over the counter selling of medications and to sell potentially dangerous chemicals in childproof containers also children must be taught the elements of safety

Multi-center studies and collaboration between poison centers all-over the country are necessary to provide a nation-wide surveillance about pattern of poisoning in Egypt and outline a unified protocol. Poison centers should respond to questions from the public and health care professionals through information service.
The intense power of the media, must participate to ensure success and increasing awareness in the community.

\section{References}

AlArifi M.N., AlMadi S. and Gubara O.A. (2003): Survey of drug information centers in Riyadh city Saudi Arabia. Arab. J. Pharm. Sci.; 2:2728.

American Academy of Pediatrics (2003): Policy Statement. Poison treatment in the home. Pediatrics; 112:1182-1185.

AnthonyL and KulkarniC (2012): Patterns of poisoning and drug overdosage and their outcome among in-patients admitted to the emergency medicine department of a tertiary care hospital. Indian J Crit Care Med. Jul-Sep; 16(3): 130-135.

Barraq A and FarahatF(2011):Pattern and determinants of poisoning in a teaching hospital in Riyadh, Saudi Arabia. Saudi Pharma J.; 19(1):57-63.

Chowdary AN, Banerjee S, Brahma A, and Biswas MK. (2007): Pesticide poisoning in nonfatal, deliberate self-harm: A public health issue. Indian J Psychiatry.;49:117-120.

El Masry MK and Tawfik HM(2013): 2011 Annual Report of the Poison Control Centre of Ain Shams University Hospital, Cairo, Egypt. Ain Shams Journal of Forensic Medicine and Clinical Toxicology; January 20: 10-17.

Gamalludin H, EL Seddawy A, Sakr M, et al. (2006): Evaluation of cases of acute poisoning received at the poison control center of Ain Shams Universiy Hospitals During the year 2005. Ain Shams J. Forensic Med. Clin. Toxicol.,Vol. VI, Jan.

Halawa H. M., Nageeb S.A., Mahmoud Kh et. al., (2013): Annual Report of the Poison Control Centre, Ain Shams University Hospitals - Cairo, Egypt, 2012. Ain Shams Journal of Forensic Medicine and Clintoxicol; Vol. 21:27-34.

IzuoraI., and Adeoye A. (2001): A seven-year review of accidental poisoning in children at a military hospital in HafrAlBatin, Saudi Arabia. Ann. Saudi Med.; 21(1-2):13-16.

Jalali A, SavariM ,Dehdardargahi S, and Azarpanah A (2012):The Pattern of Poisoning in Southwestern of Iran : Envenoming as the Major Cause. Jundishapur J Nat Pharm Prod.; 7(3):100-105.

Moazzam M, Al-Saigul A, Naguib M, et al. (2004): Pattern of acute poisoning in Al- Qassim region: a surveillance report from Saudi Arabia, 19992003, Eastern Mediterranean Health Journal, Vol. 15, No. 4.

Mowry JB, Spyker DA, Brooks DE, McMillan N and Schauben JL. (2015):2014 Annual Report of the American Association of Poison Control Centers' National Poison Data System (NPDS): 
32nd Annual Report. Clinical Toxicology ;53(10): 962-1146.

Persson H, Sjöberg G, Haines J, et al., (1998): Poisoning severity score. Grading of acute poisoning. J ToxicolClinToxicol; 36(3):205.

Rajasuriya R, Awang R, Hashim SB and RahmatHR(2007):Profile of poisoning admissions in Malaysia. Hum ExpToxicol.; 26:73-81.

Ram P, Kanchan T and Unnikrishnan B (2014): Pattern of acute poisonings in children below 15 years-a study from Mangalore, South India. J Forensic Leg Med.; 25:26-29.

RameshaK N, Krishnamurthy B H. and Ganesh S K (2009): Pattern and outcome of acute poisoning cases in a tertiary care hospital in Karnataka, India. Indian $\mathrm{J}$ Crit Care Med. Jul-Sep; 13(3):152-155.

Rhodes AE, Bethell J, Spence J, et. al., (2008): Age-sex differences in medicinal self-poisonings: a population-based study of deliberate intent and medical severity. Soc. Psychiatry Psychiatr. Epidemiol; 43(8):642-652.

Ragia Hegazy,Waleed H Almalki, Ranyah Hamdy M. Afify (2012):Pattern of Acute Poisoning in Makkah Region SAUDI ARABIA. The Egyptian Journal of Community
Medicine;30(1):21-37.

Saddique A. (2001): Poisoning in Saudi Arabia: ten-year experience in King Khalid University Hospital. Ann. Saudi Med.; 21(1-2):88-91.

Satar S and Seydaoglu G (2005): Analysis of acute adult poisoning in a 6-year period and factors affecting the hospital stay. Adv.Ther. Mar-Apr; 22(2):137-147.

Shadnia S (2007): Pattern of acute poisoning in TehranIran in 2003. Human \& experimental toxicology; 26(9):753-756.

SibertJ.,and Davies P.A. (1992):Poisoning, accidents and sudden infant death syndrome. In: Campball A.G.M., McIntosh M., editors. Forfar and Ameil's Textbook of Pediatrics. fourth ed. Churchill Livingstone; London: pp. 1777-1800.

Zhao M, Ji XP, Wang NN, Liu SY and Wang YZ(2009):Study of poisoning pattern at China Medical University from 1997 to 2007. Public Health.; 123(6):454-455.

Zhou J1, Chen SY, Li ZJ., et. al., (2005): Study of drug poisoning on 2612 cases in the department of emergency. Wei Sheng Yan Jiu. Jan; 34(1):98100. 


\section{الملخص العربي}

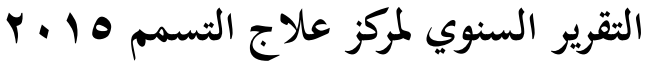

\section{محمد هاني محمد توفيق ا وايمان عبد الفتاحr}

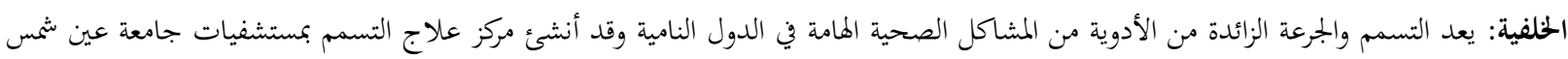

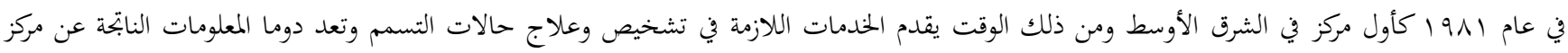

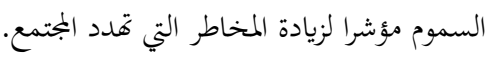

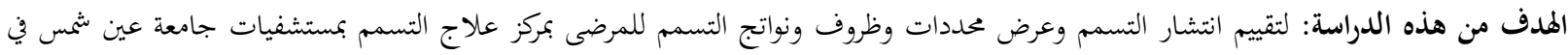

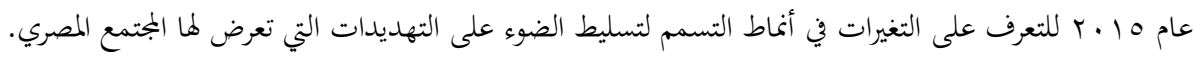

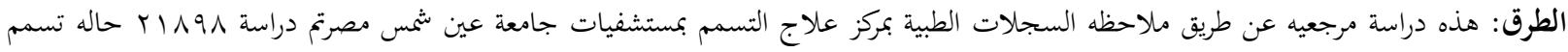

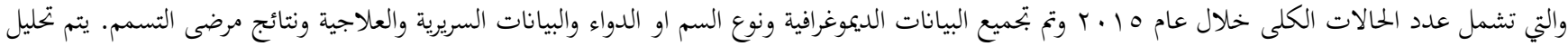
البينات باستخدام تحليل وصفي وإحصائي.

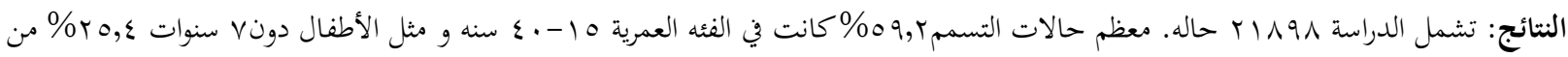

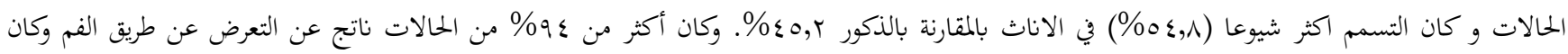

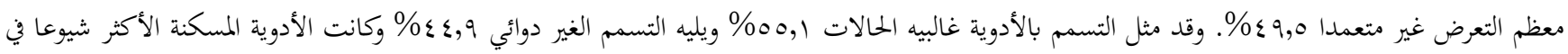

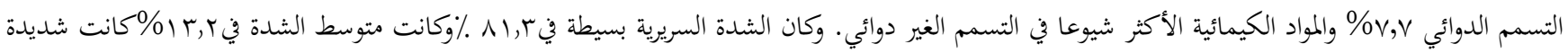

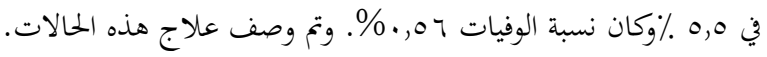

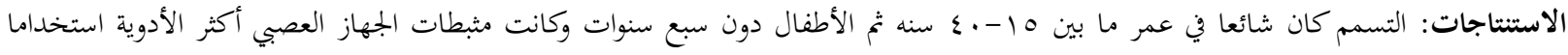
والمواد الكيمائية الأكثر شيوعا في التسمم الغير دوائي وهناك تغير في نمط التسمم حيث النفضضت اعداد حالات التسمم من الكيروسين والمواد البترولية وادويه الإدمان والتسمم بلدغات الثعابين والعقارب.

التوصيات: يوصي بتوفير برامج تدريبيه للأطباء ونشر الوعي للعامة لتقليل احتماليه التعرض والتعامل الملائم في حالات التسمم كما يجب سن التعات القوانين لحذر بيع الأدوية التي تصرف بدون تذكره طبيه ولبيع الكيماويات الخطيرة في حاويات محكمه لحماية الأطفال من المخاطر ويجب أيضا تعليم الأطفال عوامل الأمان.

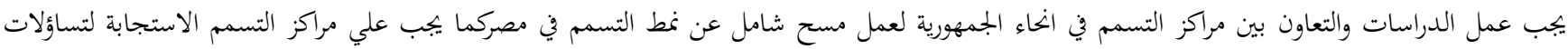

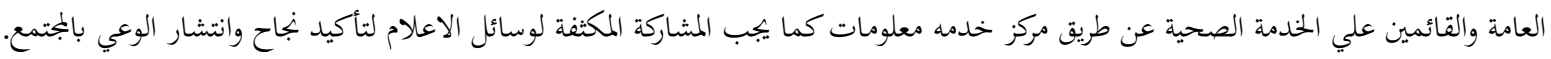

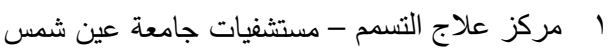

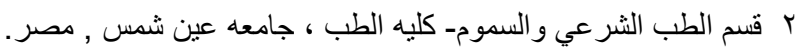

